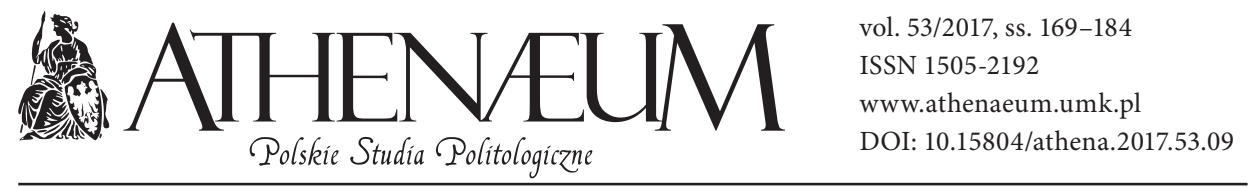

\title{
METAFORA W TELEWIZYJNYCH AUDYCJACH INFORMACYJNYCH. PRZYKŁAD KAMPANII PREZYDENCKIEJ Z 2015 ROKU
}

\author{
METAPHOR ON NEWS BULLETINS BASED ON THE EXAMPLE \\ OF PRESIDENTIAL CAMPAIGN IN 2015
}

Aleksandra Seklecka*

\begin{abstract}
ABSTRAKT
Artykuł prezentuje sposoby konstruowania wypowiedzi dziennikarskich w telewizyjnych audycjach informacyjnych na temat kampanii wyborczej. Nacisk został położony na metaforyczny charakter wypowiedzi. Uwaga została skupiona na trzech typach metafor: sportu, wojny i widowiska. Celem analizy było zaprezentowanie z jednej strony ilościowego wymiaru badanego zagadnienia, ale również jakościowej analizy wybranych wypowiedzi. Istotne było przedstawienie znaczeń, jakie wyłaniają się z prezentowanych przekazów, aby w konsekwencji ukazać, że sposób przedstawiania polityki w mediach może mieć wpływ na jej postrzeganie przez wyborców.
\end{abstract}

Słowa kluczowe: metafora, metafora sportu, metafora wojny, metafora widowiska, telewizyjna audycja informacyjna
The article presents the manners in which news concerning election campaign is constructed in news bulletins, with special emphasis on metaphorical perspective. The author focused on three kinds of metaphor: sport, war, and spectacle. The aim of the analysis is to present both the quantitative dimension of this issue and the qualitative investigation into particular statements. What is particularly interesting are the different meanings which emerge from this communication, in order to, consequently, display that the way politics is presented by the mass media could influence voters' reception.

Keywords: metaphor, sport metaphor, war metaphor, spectacle metaphor, news bulletin

* Uniwersytet Mikołaja Kopernika w Toruniu, Wydział Politologii i Studiów Międzynarodowych. 


\section{WPROWADZENIE}

Metafory są stałym elementem języka, niektóre z nich stały się niemal naturalne, a w konsekwencji niezauważalne przez uczestników danej wspólnoty językowej. $\mathrm{Z}$ drugiej strony audycja informacyjna kojarzy się przede wszystkim z wykorzystywaniem prostego stylu mowy, pozbawionego środków literackiego wyrazu. W rzeczywistości jednak dziennikarze stosują różnorodne środki stylistyczne, aby opowiadać widzom różne historie. Dlatego taki typ audycji należy postrzegać nie tylko jako gatunek czysto informacyjny.

Wybór metafor spośród różnych środków stylistycznych jest podyktowany faktem, że jest ona przedmiotem zainteresowania badaczy z różnych dyscyplin: językoznawstwa, medioznawstwa czy politologii. Ponadto metafora jest swoistą ramą, która nadaje przekazowi konkretne znaczenie i tym samym sugeruje odbiorcy sposób jego dekodowania. W konsekwencji wpływa na sam dyskurs o określonych zjawiskach czy procesach, np. o polityce.

\section{METODOLOGIA}

Przedmiotem badania są audycje informacyjne polskich stacji publicznych i prywatnych, nazywane również serwisami czy dziennikami (zob. Bogucka, 2002; Boyd, 2006; Grzmil-Tylutki, 2007; Lisowska-Magdziarz, 2008; Allan, 2006; Salski, 2012). Celem jest analiza sposobów relacjonowania wydarzeń z kampanii wyborczej w serwisach informacyjnych w kontekście wykorzystywanych metafor: sportu, wojny, widowiska. Na podstawie celów sformułowano następujące pytania badawcze:

1. Jakie elementy składają się na konstrukcję poszczególnych metafor?

2. Jakie typy metafor cieszą się największą popularnością?

3. Czy istnieje zależność (a jeśli tak to jaka) między typem metafory a tematem relacji?

4. Czy istnieje zależność (a jeśli tak to jaka) w konstruowaniu relacji między poszczególnymi nadawcami?

Postawiono również dwie hipotezy:

1. Temat relacjonowanego wydarzenia determinuje występowanie określonego typu metafory.

2. Nie ma istotnej różnicy między poszczególnymi nadawcami w odniesieniu do typu stosowanych metafor $\mathrm{w}$ relacjach $\mathrm{z}$ wydarzeń. 
Badanie zostało przeprowadzone za pomocą analizy semiotycznej. Analizowano zarówno warstwę werbalną, jak i wizualną. Istotne było porównanie sposobu relacjonowania tych samych wydarzeń przez różnych nadawców. Dodatkowo zastosowano klasyczną analizę treści. Jednostką analizy był pojedynczy materiał w audycji informacyjnej.

Serwisy do analizy zostały wybrane w sposób celowy. Były to główne wydania telewizyjnych audycji informacyjnych „Fakty” i „Wiadomości” z dwóch ostatnich tygodni prezydenckiej kampanii wyborczej z 2015 roku (11-22 maja). Wybór wyżej wymienionych audycji był spowodowany ich popularnością w rankingach oglądalności, a wybór wspomnianego okresu był podyktowany faktem, że jest to najintensywniejszy czas działań marketingowych. Rywalizacja w drugiej turze przybrała bipolarny charakter, co wpłynęło na wzrost zainteresowania kampanią mediów masowych i opinii publicznej. Analizowane były wszystkie materiały, których konstrukcja wykazywała występowanie metafory wojny, sportu lub widowiska.

\section{METAFORA - ASPEKTY TEORETYCZNE}

\section{Metafora}

Metafory towarzyszą ludziom przez całe życie, dlatego niektóre z nich (metafory ontologiczne czy orientacyjne) nie są postrzegane jako przenośnie. Niniejsze rozważania zostały oparte na rozumieniu metafory w sposób kognitywny, tak jak to przedstawiają w swoich pracach George Lakoff i Mark Johnson (zob. 1988). Metafora polega na zestawieniu ze sobą obcych znaczeniowo wyrazów, które w połączeniu przekazują znaczenie inne niż dosłowne, dlatego należy ją odczytywać w sposób nieliteralny. Metafora selekcjonuje, uwypukla, czasem wycisza i organizuje cechy przedmiotu zasadniczego, odnosząc do niego twierdzenia dotyczące zwykle przedmiotu pomocniczego. Metafora wpływa na sposób postrzegania, myślenia, działania. Ludzie widzą rzeczy nie takimi, jakie one są w obiektywnej rzeczywistości, ale jak jawią się w ich doświadczeniu. Zdaniem Jolanty Maćkiewicz (2014, s. 27) dzięki metaforze da się uwypuklić to, co pożądane, a skryć to, co niepożądane. Natomiast Andrzej Pawelec (2006, s. 15) - choć stojąc w opozycji do Lakoffa i Johnsona - wskazuje, że metafora jest „wezwaniem, by patrzeć na świat inaczej, świeżym okiem, by dostrzec w nim coś nowego". 
Mimo że Lakoff w swoich pracach używa zarówno pojęcia rama, jak i metafora, to de facto $\mathrm{w}$ wielu miejscach ta granica się zaciera. Przykładowo, kiedy mówi o metaforze „surowego ojca” i „troskliwego rodzica”, używa ram, czyli charakterystycznego sposobu narracji, który ma uwydatnić jedne cechy kosztem przykrycia innych. Jak wskazuje Lakoff (2011, s. 77-78, 128), „ludzie myślą w kategoriach ram i metafor. (...) Ramy te tkwią w naszych mózgach, wgrane - jak program - w obwody neuronowe. Kiedy fakt nie pasuje do ramy, rama jest utrzymywana, a fakt zostaje zignorowany". Dlatego wiele przekazów można ujmować w ramach (metaforach) rywalizacji sportowej, wojny czy widowiska artystycznego. Warto w tym miejscu wskazać, że każda metafora będzie ramą, ale nie każda rama będzie metaforą, gdyż tworzenie ram może opierać się na przekazie bardziej dosłownym, bez odwoływania się do nieliteralnego znaczenia znaków ${ }^{1}$.

Na metaforę, podobnie jak na ramę, składają się elementy zarówno werbalne, jak i wizualne. Przykładowo Umberto Eco (1996, s. 179) sugeruje, aby analizować wzajemne relacje wizualnej i werbalnej retoryki komunikatów. Wynika to z faktu, że obie części na siebie oddziałują. Dlatego w poniższej analizie dokonano zestawienia ze sobą obu warstw.

Lakoff i Johnson wyróżniają kilka typów metafor. Po pierwsze, są to metafory strukturalne, które najłatwiej dostrzec w przekazach, np. „mieć serce z kamienia”, „umysł zwalnia obroty”, gdzie jedno pojęcie nadaje strukturę metaforyczną innemu. Po drugie, to metafory orientacyjne (związane $z$ orientacją przestrzenną), które nie są arbitralne, bo mają podstawę w ludzkim doświadczeniu, np. „wysoka sprawność fizyczna”. Po trzecie, to metafory ontologiczne, które odnoszą się do widzenia abstrakcyjnych pojęć jako rzeczy, np.inflacji („zwalczać inflację”,„inflacja wypycha nas w ślepy zaułek”). Podobnie jak w przypadku tych orientacyjnych często nie postrzega się ich jako metafor, dlatego że służą bardzo ograniczonym celom, np. desygnacji czy kwantyfikacji (Lakoff, Johnson, 1988, s. 33, 49-50). Poza tym, są tak głęboko zakorzenione w ludzkim doświadczeniu, że nie odczytuje się ich jako przenośni.

\footnotetext{
1 Analiza ramowa skupia się na badaniu wielowarstwowych układów znaczeń, a koncepcja framingu kładzie nacisk na selekcjonowanie i uwydatnianie pewnych aspektów rzeczywistości kosztem innych. Jednakże framing może być elementem szerszej analizy ramowej. W ramowaniu wybiera się i uwydatnia te elementy, które dziennikarz uzna za ważne, właściwe, a to w konsekwencji wpływa na sposób interpretowania wydarzeń, oddziałuje zarówno na opinie odbiorców, jak i na szerszy dyskurs dotyczący danego tematu, czym zajmuje się już analiza ramowa (zob. Goffman, 2010).
} 


\section{Typy metafor}

Metafory można również podzielić ze względu na tematykę, do której się odwołują. Wcześniejsze badania eksploracyjne telewizyjnych audycji informacyjnych (zob. Seklecka, 2013; Seklecka, 2013a; Seklecka, 2014) wykazały, że w czasie kampanii wyborczych dziennikarze, tworząc relacje, opierają je na odwoływaniu się do tematyki sportowej, wojennej lub wszelkich widowisk (np. filmu, teatru, muzyki). W ten sposób przenoszą znaczenie $\mathrm{z}$ innych obszarów na sposób rozumienia działań politycznych.

Metafory sportowe w świecie polityki są szczególnie popularne - jak pokazuje poniższa analiza - do opisywania rywalizacji wyborczej. Metafory, jakie występują w dyskursach politycznych, są bardzo często mocno uzależnione od tła kulturowego danego kraju i sportów, jakie w danym społeczeństwie są popularne. Przykładowo trudno oczekiwać, aby w Polsce opierać przekazy na takich sportach jak rugby czy futbol amerykański, które nie niosą za sobą konkretnych konotacji, gdyż są mało znane w porównaniu do piłki nożnej, boksu czy różnych dyscyplin lekkoatletycznych. Zdaniem Stanisława Gałkowskiego i Agnieszki Gałkowskiej (2012, s. 63) metafora rywalizacji sportowej charakterystyczna jest szczególnie dla elekcji prezydenckiej, gdzie nie występuje problem z rozpoznaniem kandydata zwycięskiego i przegranych. W konsekwencji można zauważyć, że rodzaj wykorzystanego sportu w metaforze będzie zależał od rodzaju kampanii wyborczej. Te dyscypliny, które odwołują się do rywalizacji bipolarnej, będą charakterystyczne dla kampanii prezydenckich, szczególnie drugiej tury, a te, które odnoszą się do rywalizacji wielu zawodników, częściej mogą być stosowane w kampaniach parlamentarnych, w których bierze udział wielu kandydatów.

Do podobnej metaforyki odwołuje się również Jarosław Flis (2014, s. 22), który wskazuje, że rywalizacja polityczna jest jak metafora ligowych rozgrywek sportowych - po niepowodzeniu w jednym sezonie wyborczym partie polityczne starają się osiągnąć lepszy wynik w następnym. Popularną koncepcją w literaturze przedmiotu jest Horse race bias (metafora wyścigu). Zakłada ona, że celem mediów jest określenie pozycji konkurentów. Służy temu budowanie informacji w oparciu o wyniki sondaży, których walor informacyjny został niemalże przesłonięty przez funkcje perswazyjne i polityczne (Gulati, Just, Crigler, 2004, s. 240-241). Rywalizacja bipolarna, szczególnie w drugiej turze, jest charakterystyczna dla sportów walki, co widać na przykładzie debat telewizyjnych dwóch kandydatów. Dzięki debatom konflikt zostaje przeniesiony z pola bitwy do studia telewizyjnego, o czym pisali Daniel Dayan i Elihu Katz (zob. 2008) w książce 
Wydarzenia medialne. Historia transmitowana na żywo. Studio telewizyjne staje się ringiem, na którym walczą dwaj zwycięzcy kandydaci według wcześniej ustalonych reguł.

Kolejny typ metafory odwołuje się do tematyki wojennej, walki, rywalizacji, ale bardziej zajadłej niż w przypadku tej sportowej. W zawodach sportowych zazwyczaj nie giną ludzie, a na wojnie już tak. Sport zazwyczaj kojarzy się $\mathrm{z}$ honorową rywalizacją, a wojna $\mathrm{z}$ masowym wyniszczeniem przeciwnika. Dlatego odwoływanie się do przedmiotowej metaforyki niesie za sobą większy ładunek emocjonalny. Mechanizm rywalizacji znany jest już z Biblii. Świadczy o tym chociażby historia o Ablu i Kainie. Współcześnie wielokrotnie w różnych sytuacjach można spotkać się z metaforami odwołującymi się do przedmiotowej tematyki, np. „zabić kogoś wzrokiem”, „zabić czas”. W ten sposób dokonuje się hiperbolizacji rzeczywistości, nadaje się przekazowi wyrazistości. Pisze o tym Lakoff (zob. 1991) w artykule o metaforach stosowanych przez władze amerykańskie, by usprawiedliwić zaangażowanie amerykańskich wojsk w wojnę w Zatoce Perskiej w 1991 roku. Jego zdaniem „metafory potrafią zabijać”, ponieważ ten językowy środek stylistyczny jest odbiciem metaforycznego sposobu myślenia, który kieruje ludzkim rozumowaniem, ale także działaniem - tak w życiu codziennym, jak i w polityce. W polityce metafory rzadko są tylko odizolowanymi słownymi ozdobnikami. Zazwyczaj tworzą cały system konceptualny, a najczęściej - odzwierciedlają system moralny tych, którzy ich używają (Lakoff, 2013). W konsekwencji postrzeganie działań politycznych jako wojny może doprowadzać do zachowań, które będą coraz brutalniejsze i będą stanowić usprawiedliwienie dla aktorów politycznych.

Ostatnia metafora, nazwana przez autorkę metaforą widowiska, polega na opisywaniu rzeczywistości politycznej poprzez odwoływanie się do wszelkiego rodzaju zawodów scenicznych, np. filmu, teatru, piosenki czy malarstwa. Działania takie wynikają z faktu, że główną cechą kultury masowej jest jej ludyczność, szczególnie ludyczność telewizyjna (zob. Piechota, Stachyra, Nowak, 2010), a telewizyjne audycje informacyjne również do tej kultury należą. Dyskurs ludyczny to „typ wydarzeń komunikacyjnych, w których przekazywaną ideą jest skłonność do zabawy, a celem interakcji tworzenie "wspólnoty śmiechu»" (Brzozowska, 2009, s. 150). O takiej skłonności pisał Johan Huizinga (zob. 1967) w książce Homo ludens. Zabawa jako źródło kultury, wskazując, że w sferze zabawy nie obowiązują prawa i obyczaje pospolitego życia. W celu przyciągnięcia uwagi masowego odbiorcy przekazy są upraszczane, obudowywane ironią, lekką narracją, po to, aby oddziaływać raczej na poziomie emocjonalnym i wrażeniowym. 
Konsekwencją pokazywania ludycznego wymiaru polityki może być traktowanie jej przez wyborców mało poważnie. Z drugiej strony ludyczna perspektywa pozwala usprawiedliwić działania aktorów politycznych - podobnie jak ta rywalizacyjna - którzy postrzegani są bardziej jako błaźni na dworze królewskim, którym wolno przekraczać granice, za co nie zostaną ukarani, bo traktuje się ich $\mathrm{z}$ „przymrużeniem oka”2.

\section{WYNIKI BADAŃ}

Badaniem objęto 20 wydań audycji informacyjnych od 11 maja do 22 maja 2015 roku, 10 głównych wydań „Faktów” i 10 - „Wiadomości”. Z przyczyn technicznych autorka musiała usunąć z próby badawczej serwis z 15 maja. Analizowane audycje pochodzą z drugiej tury kampanii prezydenckiej i cechują się stosunkowo dużym udziałem informacji z kampanii w porównaniu $\mathrm{z}$ audycjami z wcześniejszego etapu. Co więcej, w badanym okresie kampania wyborcza dwóch kandydatów na prezydenta: Bronisława Komorowskiego i Andrzeja Dudy nabrała intensywności ze względu na utratę pozycji lidera przez urzędującego prezydenta i wysokie poparcie dla Pawła Kukiza (20,8\%).

W badanych relacjach dziennikarze głównie stosowali trzy typy opisanych powyżej metafor, co prezentują tabele (1 i 2 ).

Tabela 1. Metafory w "Faktach"

\begin{tabular}{|c|c|c|c|c|}
\hline Data/metafora & Sport & Wojna & Widowisko & Suma \\
\hline 11.05 & 17 & 10 & 2 & 29 \\
\hline 12.05 & 0 & 1 & 0 & 1 \\
\hline 13.05 & 1 & 1 & 1 & 3 \\
\hline 14.05 & 0 & 1 & 2 & 3 \\
\hline 16.05 & 0 & 2 & 0 & 2 \\
\hline 17.05 & 4 & 0 & 0 & 4 \\
\hline 18.05 & 5 & 2 & 2 & 9 \\
\hline 19.05 & 3 & 6 & 5 & 14 \\
\hline
\end{tabular}

2 O roli karnawalizacji w polityce, która opiera się na tej ludycznej perspektywie, pisał Marek Jeziński (zob. 2007). 


\begin{tabular}{|c|c|c|c|c|}
\hline Data/metafora & Sport & Wojna & Widowisko & Suma \\
\hline 20.05 & 3 & 2 & 5 & 10 \\
\hline 22.05 & 6 & 1 & 2 & 9 \\
\hline SUMA & 39 & 26 & 19 & 84 \\
\hline
\end{tabular}

Źródło: Opracowanie własne.

Tabela 2. Metafory W „Wiadomościach”

\begin{tabular}{|c|c|c|c|c|}
\hline Data/metafora & Sport & Wojna & Widowisko & Suma \\
\hline 11.05 & 7 & 3 & 0 & 10 \\
\hline 12.05 & 1 & 5 & 0 & 6 \\
\hline 13.05 & 1 & 7 & 2 & 10 \\
\hline 14.05 & 4 & 1 & 9 & 14 \\
\hline 16.05 & 3 & 1 & 0 & 4 \\
\hline 17.05 & 4 & 10 & 2 & 16 \\
\hline 18.05 & 2 & 0 & 1 & 3 \\
\hline 19.05 & 1 & 2 & 1 & 4 \\
\hline 20.05 & 3 & 2 & 1 & 6 \\
\hline 22.05 & 7 & 8 & 2 & 17 \\
\hline SUMA & 33 & 39 & 18 & 90 \\
\hline
\end{tabular}

Źródło: Opracowanie własne.

W analizowanych materiałach znalazły się również przenośnie oparte o inne konotacje, ale nie zostały one uwzględnione w prezentacji wyników niniejszego badania. Poniżej przeanalizowano po trzy przykładowe wypowiedzi odnoszące się do każdego z wyróżnionych typów metafor. Na koniec przedstawiono trzy przykłady łączenia metafor. Analiza języka została połączona z analizą obrazu.

\section{METAFORA SPORTU}

Stosowanie metaforyki sportowej obrazuje następująca wypowiedź prezenterki „Faktów” (11.05.): „Andrzej Duda prowadzi, Bronisław Komorowski goni, a Paweł Kukiz staje się więcej niż czarnym koniem i sponad $20 \%$ galopuje do polityki”. Informacja dotyczy wyników sondaży (exit pool) po pierwszej turze 
wyborów i reakcji na nie sztabów wyborczych. Na poziomie denotacyjnym w warstwie wizualnej widać prezenterkę, która stoi (plan pełny - widoczna cała postać), za nią w tle (videowall) zostało umieszczone zdjęcie Dudy w półzbliżeniu, który trzyma rękę w geście zwycięstwa (znak V - symbol zwycięstwa), co może sugerować, iż w tej rywalizacji zajął pierwsze miejsce, oraz Komorowskiego, który trzyma rękę na piersi. Za nimi w pewnym oddaleniu jest Kukiz z mikrofonem w ręku. Jego postać jest wyraźnie mniejsza od pozostałych rywali, co na poziomie konotacyjnym można odczytywać jako kandydata, którego wynik jest słabszy od pozostałych dwóch rywali. Jednak w warstwie werbalnej prezenterka podkreśla, że $20 \%$ poparcie wyborców to bardzo dobry wynik, co może sugerować, iż trzecie miejsce Kukiza jest dla niego wielkim sukcesem. Wynikało to z faktu, że nigdy wcześniej w wyborach prezydenckich kandydat sklasyfikowany na trzecim miejscu nie otrzymał takiego wysokiego poparcia. Media prezentowały Kukiza w roli nieformalnego zwycięzcy w pierwszej turze. W zaprezentowanej wypowiedzi politycy są prezentowani niczym zawodnicy na podium. Duda to nieoczekiwany zwycięzca. Komorowski to przegrany, niekwestionowany faworyt. Kukiza można było spodziewać się na podium, ale jego wynik był naprawdę największym zaskoczeniem.

Kolejna wypowiedź znalazła się w „Wiadomościach” (19.05.) w relacji reportera: „Wyścig do fotela w pałacu prezydenckim staje się coraz szybszy i coraz bardziej zacięty”. Materiał dotyczył kampanii prowadzonej przez Komorowskiego. Zdanie wypowiedziane przez reportera ma charakter metafory sportowej. Nasuwa się skojarzenie z wyścigiem F1, ewentualnie wyścigiem koni (Horse race bias). W wypowiedzi występuje również metonimia: „wyścig do fotela". W warstwie wizualnej przedstawiono Komorowskiego witającego się ze swoimi zwolennikami. Dalsze ujęcie przedstawia przeciwników prezydenta, którzy skandują hasła przeciw politykowi.

Następny fragment: „Zaskakujące zagrywki i uniki przy niewygodnych pytaniach. Kto wypadł lepiej, kto był zwycięzcą", pochodzi z wprowadzenia do jednego z materiałów prezentera „Faktów” (22.05.). Relacja dotyczy ocen debaty, jaka odbyła się dzień wcześniej w studiu TVN. Ma ona charakter metafory sportowej. Zagrywki to typowy komponent dla piłki siatkowej, a uniki kojarzą się z walką bokserską. Debaty telewizyjne kandydatów na prezydenta są niczym pojedynek bokserski o pas mistrza świata. Sam pojedynek jest tylko częścią innego wydarzenia. Ważny jest też czas poprzedzający ten pojedynek oraz dzień po walce. Najważniejsza część rozgrywa się na ringu. Wcześniej jednak agenci (promotorzy) obu zawodników uzgadniają warunki walki (miejsce, liczbę rund, 
wysokość gaży dla zawodników). Wypowiedź może sugerować, iż kandydaci stosowali różne sztuczki, aby dobrze wypaść i zagrozić przeciwnikowi, z drugiej strony - unikali odpowiedzi na wszystkie pytania. Rzeczownik „zwycięzca” można kojarzyć też z metaforą wojny, jednak znaki te działają na zasadzie syntagmy. Pierwsze zdanie nadaje sens drugiemu - skoro pierwsze odnosiło się do metafory sportowej, to drugie przejmuje jego znaczenie. W warstwie wizualnej widać prowadzącego siedzącego za stołem prezenterskim, a w tle kandydatów w niemalże identycznej pozie: $\mathrm{z}$ uniesioną ręką i wysuniętym palcem. Ten gest może sugerować przekonywanie.

\section{METAFORA WOJNY}

Do metafory wojennej odwołał się reporter „Wiadomości” (11.05.) w wypowiedzi: „Ofensywa Andrzeja Dudy ma być przeprowadzona na wielu frontach”. Relacja dotyczy taktyki, jaką ma przyjąć Duda w drugiej turze wyborów. Termin ofensywa można rozumieć jako etap działań taktycznych, które będą polegać na zastosowaniu wielu technik. Ta militarna terminologia ma podkreślić, że w walce „jeden na jednego" tylko zdecydowanie i stawianie wszystkiego na jedną kartę może przynieść zwycięstwo. W warstwie wizualnej widać kandydata, który idzie ulicą wśród tłumów i rozmawia ze swoimi zwolennikami.

Kolejny fragment: „Po raz pierwszy staną naprzeciw siebie. Czy ta batalia może być decydująca. Ostatnie odliczanie do debaty Komorowski-Duda”, został wypowiedziany przez prezenterkę „Wiadomości” (17.05.) relacjonującą debatę kandydatów na prezydenta. Ta wypowiedź miała miejsce na początku serwisu, w czasie przywitania. Były to pierwsze zdania, jakie wypowiedziała prowadząca, wskazując na temat dnia. Wypowiedź zaprezentowana jest jako metafora wojny. Już pierwsze zdanie sugeruje, że kandydaci niczym wrogie armie staną naprzeciwko siebie. Słowo „batalia” ma zwrócić uwagę, iż będzie to bardzo ciężkie spotkanie, które może wpłynąć na wynik wyborów prezydenckich. Ostatnie zdanie potęguje nastrój, jest niczym odliczanie przed wystrzałem rakiety. W warstwie wizualnej nie ma dodatkowych wzmocnień: widać prezenterkę, najpierw w pełnym planie, potem następuje najazd kamery do planu średniego. $\mathrm{W}$ tle na videowallu umieszczono obraz charakterystyczny dla czołówki serwisu (niebo).

Przykładem przedmiotowej metaforki jest wypowiedź prezenterki „Faktów” (19.05.): „Negocjują warunki debaty i zagrzewają do walki. W przeciwnika celują z drugiego szeregu”. Materiał dotyczył roli doradców kandydatów: Michała 
Kamińskiego i Jacka Kurskiego. Jest to ostatni materiał w serwisie („michałek”) i ma ironiczny wydźwięk. W dalszej części wypowiedzi pojawia się metafora widowiska („ale bardzo lubią być na pierwszym planie”), która może sugerować, że doradcy kandydatów, choć powinni być niewidoczni, bardzo lubią kamery i wywiady. Sama wypowiedź jest metaforą wojny: negocjowanie warunków, zagrzewanie do walki, celowanie w przeciwnika. Może być również charakterystyczna dla budowania napięcia przed walką bokserską. Wskazuje, że konsultanci są prowodyrami negatywnej kampanii, to oni sugerują kandydatom nieczyste zagrywki. W gruncie rzeczy są niczym „szare eminencje”, choć nie do końca szare, bo pokazują się przed kamerami i wszyscy ich znają. W warstwie wizualnej widać prezenterkę, a po jej prawej stronie, na „ozdobniku” - Kamińskiego i Kurskiego, którzy wyglądają tak, jakby mówili jednocześnie, kłócili się (zdjęcie pochodzi z programu Moniki Olejnik „Kropka nad i”).

\section{METAFORA WIDOWISKA (SPEKTAKLU)}

Ilustracją metafory widowiska, czyli takiej, która odwołuje się do różnych dziedzin scenicznych, jest wypowiedź reportera „Wiadomości” (13.05.): „Agitacje na ulicach Warszawy, odsłona druga". Materiał dotyczy sposobu, w jaki kandydaci prowadzą kampanię: wychodzą na ulice do ludzi i składają liczne obietnice. W dalszej kolejności pojawia się zapowiedź ówczesnego prezydenta w sprawie ogłoszenia referendum. Powyższe zdanie można powiązać z metaforą widowiska. Tak jak w teatrze są akty, tak i w polityce jest akt drugi, czyli druga tura wyborów. Jednocześnie wypowiedź nie zawiera czasownika, tylko rzeczowniki odczasownikowe (agitacje, odsłona), co może konotować z tytułem tej wypowiedzi (to jest pierwsze zdanie reportera). Warstwa wizualna koresponduje z werbalną: widać Komarowskiego idącego ulicą wśród tłumów (głównie dziennikarzy).

Kolejny przykład: „Spektakl reżyserowało życie, sytuacja była dynamiczna, a suflująca nie miała wglądu do scenariusza. Dużo w tym było improwizacji”, to wypowiedź reportera „Wiadomości” (14.05.). Relacja dotyczy sposobu, w jaki kandydaci są „sterowani” przez specjalistów od marketingu politycznego. $\mathrm{Na}$ poziomie denotacyjnym w warstwie wizualnej widać kobietę podpowiadającą prezydentowi stojącemu wśród tłumów ludzi kolejne wypowiedzi (świadczą o tym jej gesty i wypowiadane cicho słowa). Osoba ta stała się przedmiotem dużego zainteresowania mediów i konkurencji politycznej. W tym fragmencie dziennikarz porównał ją do suflerki w teatrze, która podpowiada aktorom tekst 
(takie miano nadano jej w mediach, być może nawet pierwsi tego terminu użyli politycy PiS). Ta metafora wskazuje, że kampania wyborcza jest jak spektakl, którego nie da się do końca wyreżyserować, czasem aktorzy muszą improwizować, bo i suflerzy nie znają scenariusza. Fragment: „sytuacja dynamiczna” pochodzi z filmu „Drogówka” (reż. Wojciech Smarzowski), gdzie jeden z policjantów na przesłuchaniu wypowiada: „Z kim ja piłem wczoraj, nie pamiętam, sytuacja dynamiczna”.W całym materiale znajdują się również kadry z kampanii Komorowskiego i Dudy (również on miał suflerkę: Beatę Szydło). Całość tworzy syntagma między ujęciami polityków i ich suflerów i ujęć ze sztuki teatralnej, gdzie suflerka podpowiada aktorom ich tekst. Cały materiał ma wydźwięk prześmiewczy, zabawowy, ludyczny.

Kolejna wypowiedź: „I to nie koniec serialu kampanijnego” została wypowiedziana przez prezenterkę „Faktów” (18.05.) po wyemitowaniu jednego z materiałów i stanowi puentę do relacji o kampanii Dudy inspirowanej amerykańskim serialem „House of Cards”. Zdanie jest też zaproszeniem do wywiadu z politykami w TVN24 („Fakty po Faktach”). Poprzez metaforę widowiska (serialu) wskazuje się, iż polityka, a przede wszystkim kampania, to opowieść wieloodcinkowa. Z uwagi, że jest to ostatni materiał („michałek”), ma on charakter ironiczny i może sugerować, że polityka tak jak serial jest mało realna. Warstwa wizualna nie dopełnia tej werbalnej, gdyż widać prezenterkę, a w tle fragment zdjęcia z czołówki serwisu.

\section{ŁĄCZENIE METAFOR}

Wiele wypowiedzi dziennikarzy jest opartych na łączeniu w sobie różnych typów metafor. Przykładem jest wprowadzenie prezenterki „Faktów” (11.05.) „Jeden na jednego, twarzą w twarz w walce na argumenty i program. Stawka jest dość wysoka. Prezydencka debata to show najwyżej próby. Można w niej dużo wygrać i wszystko przegrać”. Prowadząca zapowiada materiał o przyszłych debatach, na które zgodzili się obaj kandydaci. Występują tu trzy rodzaje analizowanych metafor. Pierwsze zdanie zawiera w sobie odwołanie do sportów w walki: boksu, judo itp., oraz wojny (walka na argumenty i program). Co ciekawe, można tu doszukać się pleonazmu: program jest częścią argumentacji. Drugie zdanie to metafora sportu, np. stawka meczu. Trzecie zdanie to metafora widowiska, co mogłoby wskazywać, że debata jest bardzo wymagającym spotkaniem, które odsłoni słabości kandydatów, ale pokaże też ich mocne strony. Taka argumen- 
tacja sugerowałaby też nawiązanie do metafory sportu. Ostatnie zdanie znów nawiązuje do terminologii sportowej. W oknie po lewej stronie prowadzącego („ozdobnik”) widać zdjęcia twarzy Komorowskiego i Dudy zwrócone ku sobie. Na poziomie konotacyjnym można odczytać to jako stawanie do walki bokserskiej. Z tymże Dudę widać z profilu, a Komorowskiego z półprofilu, jego twarz zwrócona jest ku widzom, tak jakby nie chciał stanąć do walki, wahał się, co można powiązać z faktem, że w pierwszej turze kampanii ówczesny prezydent konsekwentnie odmawiał przystąpienia do debaty. Tę rywalizację ma sugerować tytuł materiału („Twarzą w twarz”), który podkreśla, że będzie to bezpośrednia konfrontacja kandydatów. Przedmiot rywalizacji (fragment pałacu prezydenckiego) jest widoczny w tle, na „ozdobniku”.

Kolejna wypowiedź stanowi wprowadzenie do materiału wypowiedzianego przez prezentera „Faktów” (20.05.): „Finał kampanii jak u Alfreda Hitchcocka. Były eksplozje, ale napięcie ciągle rośnie. Bronisław Komorowski celuje w emerytury. 40 lat pracy wystarczy i chce zmienić ustawę. To ma być kolejny as. Pytanie czemu te asy czekały w rękawie tyle czasu”. Relacja dotyczy kampanii Komorowskiego. Występują tu trzy typy metafor. „Finał kampanii” odwołuje się do terminologii sportowej, jednak samo przywołanie nazwiska słynnego reżysera wskazuje na metaforę widowiska. Kolejne zdanie sugeruje fabułę jakiegoś filmu akcji. Trzecie zdanie kojarzy się ze snajperem, który stara się trafić jak najskuteczniej w sam środek, tym środkiem dla polityka jest zmiana ustawy emerytalnej na korzyść pracowników. Ostatnie dwa zdania odnoszą się do terminologii charakterystycznej dla gier w karty. W warstwie wizualnej pojawia się reporterka w pełnym planie, po chwili kamera się zbliża i pozostaje ona w planie amerykańskim. W tle widać Komorowskiego z uniesioną do góry ręką (pozdrawia tłum). $\mathrm{W}$ jego tle pojawiają się zwolennicy ubrani w koszulki z napisem Bronisław Komorowski i kartkami: „Głosuję na Bronka”. Po jego prawej stronie znajduje się urna wyborcza, po lewej ster statku, człowiek ubrany w strój marynarza (kapitan). Te atrybuty można powiązać z warstwą werbalną: „Finał kampanii jak u Hitchcocka”. Ciekawostką jest fakt, że materiał był emitowany w środę, finał kampanii był dopiero w piątek. Na poziomie konotacyjnym można odczytać ten tekst jako walkę do ostatniej chwili. Zachodzi jednak pewna niespójność w warstwie werbalnej i wizualnej. O ile obrazy sugerują odczytanie przekazu jako triumfu w wyborach (urna, gest Komorowskiego i ster), o tyle w warstwie werbalnej chodzi o taktykę, jaką prezentuje sztab kandydata.

Ostatni przykład: „Na finiszu kampanii obaj kandydaci sięgnęli po najbliższy sercu oręż - rodzinę. (...). Słodko było tylko w rodzinnym gronie, wymieniając 
ciosy kandydaci już nie przebierali w słowach” pochodzi z „Wiadomości” (22.05.) i dotyczy podsumowania kampanii obu kandydatów. Wypowiedź reporterki zawiera kilka metafor. „Finisz kampanii” to przykład terminologii sportowej. "Oręż” kojarzy się z walką, wojną. „Wymiana ciosów” to znowu przywołanie tematyki sportowej, bokserskiej. Warstwa wizualna koresponduje z tą werbalną. Na początku widać ujęcie Dudy i jego córki robiących selfie. Później pojawia się ujęcie ze spotu rodzinnego Komarowskiego, a potem - uścisk Dudy z żoną i córką. Gdy pojawiło się słowo „ciosy”, nastąpiło zestawienie wypowiedzi Komorowskiego z wypowiedzią Dudy, w których oskarżają się siebie nawzajem.

\section{PODSUMOWANIE}

Zaprezentowane powyżej przykłady stanowią jedynie niewielki fragment obrazujący sposób konstruowania przekazów o polityce, a konkretnie - o kampanii wyborczej. Poszczególne metafory składają się z wyrażeń (rzeczowników, czasowników, przymiotników) charakterystycznych dla danego obszaru (sportu, wojny, widowiska). Wypowiedzi wzmacniane są przez warstwę wizualną, która zazwyczaj koresponduje z warstwą werbalną. Dominują przekazy oparte o metaforę sportową i wojenną, rzadziej pojawiają się te odnoszące się do metafory widowiska. Badanie nie wykazało konkretnej zależności między typem metafory a tematem relacji. Zazwyczaj tematyka sportowa i wojenna pojawiają się wymiennie. W konsekwencji należy uznać, iż hipoteza pierwsza nie została potwierdzona. Biorąc pod uwagę wszystkie analizowane audycje, nie ma istotnej różnicy między poszczególnymi nadawcami w konstruowania przekazów opartych na określonej metaforyce. Wynikać to może z korzystania przez dziennikarzy newsowych z tych samych wypowiedzi polityków, którzy sami odwołują się do bogatej stylistyki. Różnice pojawiają się w liczbie stosowanych metafor w ramach poszczególnych dni, ale jest to związane $\mathrm{z}$ liczbą materiałów poświęconych kampanii, dlatego należy uznać, że hipoteza druga została potwierdzona.

Najczęściej powtarzane metafory (w różnych serwisach) to przykładowo „Żółta kartka dla prezydenta Komorowskiego”, oznaczająca ostrzeżenie wyborców po pierwszej turze wyborów, kiedy uzyskał niższe poparcie, niż zakładały sondaże. Kolejne popularne frazy to: „ostatnia prosta”, „finisz kampanii”, „finał kampanii” oznaczające koniec rywalizacji wyborczej. Co ciekawe, były one powtarzane nie tylko w ostatnim dniu kampanii wyborczej, ale nawet na trzy dni przed jej końcem. Popularnym zwrotem była również „mobilizacja elekto- 
ratu" sugerująca pobudzenie do działania wyborców, czyli do agitowania czy głosowania.

W analizowanych materiałach dziennikarze stosują również inne metafory, takie jak: „rzucać się w oczy” czy „nie dzielić skóry na niedźwiedziu”, jednak metaforyka sportowa, wojenna i widowiska jest szczególnie widoczna. Można również zauważyć tendencję do łączenia ze sobą metafor sportowych poprzez odwoływanie się do różnych dyscyplin sportowych oraz łączenie różnych typów metafor, co może sugerować niespójność przekazu. Jednak de facto hiperbolizuje ten przekaz, wyróżnia go i uwydatnia poszczególne jego fragmenty.

\section{BibLIOGRAFIA:}

Allan, S. (2006). Kultura newsów. Kraków: Wydawnictwo Uniwersytetu Jagiellońskiego. Bogucka, T. (2002). Triumfujace profanum. Telewizja po przełomie 1989. Warszawa: Sic!. Boyd, A. (2006). Dziennikarstwo radiowo-telewizyjne. Techniki tworzenia programów informacyjnych. Kraków: Wydawnictwo Uniwersytetu Jagiellońskiego.

Brzozowska, D. (2009). Słownictwo polskiego dyskursu ludycznego i jego kulturowe konteksty. Tekst $i$ dyskurs, $n r$ 2. Pobrane z: http://bazhum.muzhp.pl/media// files/Tekst_i_Dyskurs_Text_und_Diskurs/Tekst_i_Dyskurs_Text_und_Diskurs-r2009-t2/Tekst_i_Dyskurs_Text_und_Diskurs-r2009-t2-s149-161/Tekst_i_Dyskurs_Text_und_Diskurs-r2009-t2-s149-161.pdf.

Dayan, D., Katz, E. (2008). Wydarzenia medialne. Historia transmitowana na żywo. Warszawa: Muza.

Eco, U. (1996). Nieobecna struktura. Warszawa: Wyd. KR.

Flis, J. (2014). Zludzenia wyboru. Społeczne wyobrażenia i instytucjonalne ramy w wyborach do sejmu i senatu. Kraków: Wydawnictwo Uniwersytetu Jagiellońskiego.

Gałkowski, S., Gałkowska, A. (2012). Personalizacja polityki. Państwo i Społeczeństwo, $n r 1$, s. 55-71.

Goffman, E. (2010). Analiza ramowa. Kraków: Nomos.

Grzmil-Tylutki, H. (2007). Gatunek w świetle francuskiej teorii dyskursu. Kraków: Universitas.

Gulati, G.J., Just, M.R., Crigler, A.N. (2004). News Coverage of Political Campaigns. W: L.L. Kaid (red.), Handbook of Political Communiction Research (s. 237-256). New Jersey: Lawrence Erlbaum Associates Publishers.

Huizinga, J. (1967). Homo ludens: zabawa jako źródło kultury. Warszawa: Czytelnik. Jeziński, M. (2007). Marketing polityczny i karnawał. Uwagi na marginesie wyborów roku 2005. W: T. Sasińska-Klas (red.), Media w wyborach. Kampanie wyborcze. Media w polityce (s. 195-210). Torun: Wydawnictwo Adam Marszałek.

Lakoff, G. (1991). Metaphor and War. The Metaphor System Used to Justify War in the Gulf. Pobrane z: https://georgelakoff.files.wordpress.com/2011/04/metaphor-andwar-the-metaphor-system-used-to-justify-war-in-the-gulf-lakoff-1991.pdf. 
Lakoff, G. (2011). Nie myśl o słoniu!: jak język kształtuje politykę. Warszawa: Oficyna Wydawnicza Łośgraf.

Lakoff, G. (2013). Metafory ida na wojnę. Pobrane z: http://www.tokfm.pl/blogi/instytut-obywat/2013/09/lakoff_metafory_ida_na_wojne/1.

Lakoff, G., Johnson, M. (1988). Metafory w naszym życiu. Warszawa: PIW.

Lisowska-Magdziarz, M. (2008). Media powszednie. Środki komunikowania masowego i szerokie paradygmaty medialne w życiu codziennym Polaków u progu XXI wieku. Kraków: Wydawnictwo Uniwersytetu Jagiellońskiego.

Maćkiewicz, J. (2014). Co językoznawstwo może dać medioznawstwu?. W: T. Gackowski (red.), Metodologie badań medioznawczych (s. 17-33). Warszawa: Oficyna Wydawnicza ASPRA-JR.

Pawelec, A. (2006). Metafora pojęciowa a tradycja. Kraków: Universitas.

Piechota, M., Grażyna, S., Nowak, P. (2012). Rozrywka w mediach $i$ komunikacji spotecznej. Wybrane zagadnienia. Lublin: WSPA.

Salski, M. (2014). Dziennikarz na wizji. Szczecin: Wyd. US.

Seklecka, A. (2013). Rytuał medialny w serwisach informacyjnych. Przypadek kampanii wyborczej 2011 roku. W: M. Adamik-Szysiak, W. Maguś, Współczesne zagadnienia marketingu politycznego i public relations (s. 259-276). Lublin: Wyd. UMCS.

Seklecka, A. (2013a). The Picture(s) of Campaign. The 2011 Electoral Campaign in Major News Bulletins. Political Preferences, nr 4, s. 153-167.

Seklecka, A. (2014). Rytuał medialny jako przykład uniformizacji przekazu informacji. Athenaeum. Polskie Studia Politologiczne, nr 41, s. 249-267. 